\title{
Studi etnobotani di kawasan kars Bukit Bulan untuk mendukung studi arkeologi
}

\author{
Ethnobotany study in the Bukit Bulan karst area to support archeological
}

\author{
Dhanang Puspita ${ }^{a}$, Soenarto Notosoedarmo ${ }^{a}$, M Rully Fauzi ${ }^{b}$ \\ a Teknologi Pangan, Fakultas Kedokteran dan Ilmu Kesehatan, Universitas Kriseten Satya Wacana, J1 Kartini No.11A Salatiga, \\ 50711, Indonesia [+62 85640035216] \\ ${ }^{\mathrm{b}}$ Balai Arkeologi Sumatera Selatan, Jl. Kancil Putih Lr. Rusa Demang Lebar Daun Palembang, Sumatera Selatan, Indonesia [+2711- \\ 445247]
}

\section{Article Info:}

Received: 04 - 10 - 2019

Accepted: 03 - 06 - 2020

Keywords:

Archeology, Bukit Bulan, etnobotany, karst

Corresponding Author: Dhanang Puspita

Teknologi Pangan, Universitas

Kristen Satya Wacana;

Tel. +6285640035216

Email:

Dhanang.puspita@uksw.edu

How to cite (CSE Style $8^{\text {th }}$ Edition):

Puspita D, Notosoedarmo S, Fauzy MR. 2020. Studi etnobotani di kawasan kars bukit bulan untuk mendukung studi arkeologi. JPSL 10(2): 270-283. http://dx.doi.org/10.29244/jpsl.10.2.270-283.

\section{PENDAHULUAN}

Indonesia memiliki luasan kawasan kars hampir 20\% dari luas wilayahnya. Kawasan ini hampir terdapat pada masing-masing kawasan di Indonesia. Kars sebagai salah satu ekosistem yang unik, memberikan peran ekologi yang vital bagi manusia. Kars mampu memberikan pasokan air, penyedia lahan pemanenan walet, wisata, tambang, dan lain sebagainya (Adji dan Haryono, 1999). Salah satu sumber daya alam (SDA) yang terdapat di kars adalah sumber daya hayati.

Kars Bukit Bulan adalah bentang alam yang di dalamnya terdapat bukit-bukit gamping yang memiliki nilai ekologi, hidrologi, sosial ekonomi, dan ilmu pengetahuan (Gambar 1). Kawasan kars ini terdapat di Kecamatan Limun, Kabupaten Sarolangun, Provinsi Jambi. Kawasan ini masuk dalam kategori kelas I, II, dan III, dimana kelas I kawasan perlindungan SDA, kelas II sebagai kawasan perlindungan dan budidaya, dan kelas III sebagai kawasn lindung yang memiliki nilai sosial budaya, ilmu pengetahuan, dan pariwisata (Oktariadi dan Tarwedi, 2011).

Sebagai ekosistem yang didominasi batu gamping, kars memiliki lapisan tanah yang tipis. Tipisnya lapisan tanah tersebut tidak mampu menyimpan air, sehingga kars identik dengan daerah yang kering. Flora dan fauna yang tinggal di daerah khas memiliki karakteristik tersendiri, dimana harus dapat beradaptasi dengan lingkungan yang kering. Botani adalah salah satu cabang ilmu yang memelajari tentang flora, dan pada 
panelitian ini mengarah pada vegetasi kars. Vegetasi kars memiliki ciri khas, baik bentuk dan komposisi spesiesnya. Tumbuhan yang hidup di kawasan kars biasanya berdaun kecil dan bertajuk jarang, menempel di tebing. Tumbuhan kars banyak didominasi oleh tumbuhan pioner seperti; lumut, paku, dan jenis rerumputan, dan semak (Widiyanti dan Kusmana, 2014)

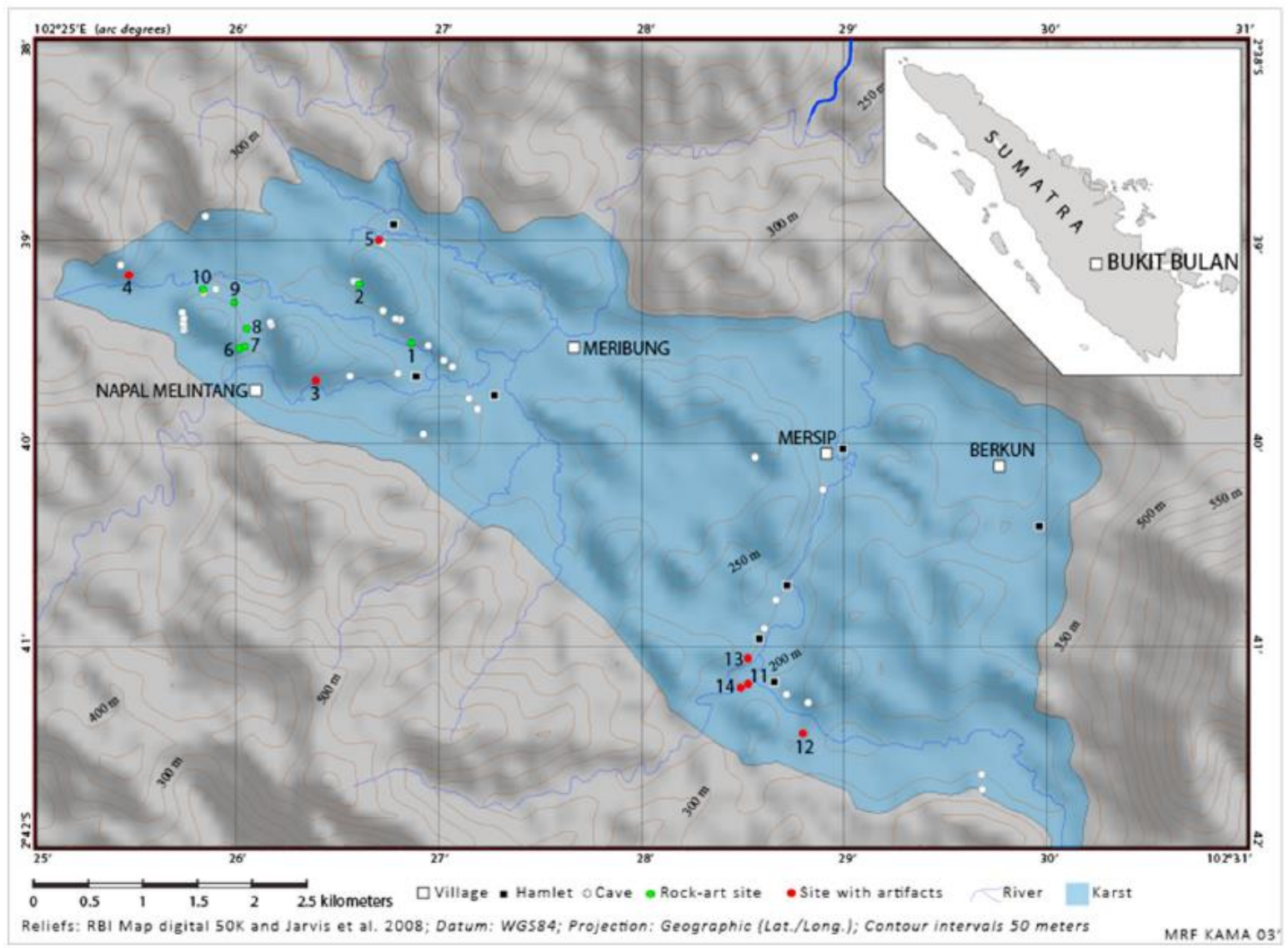

Gambar 1 Peta kawasan Kars Bukit Bulan

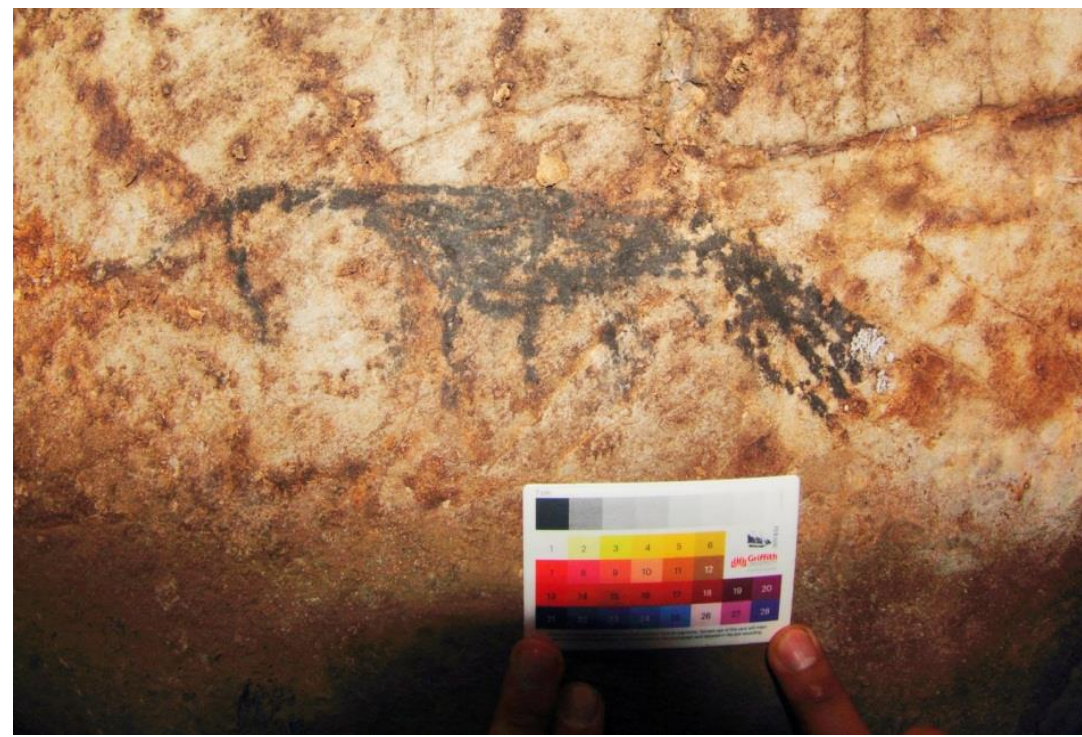

Gambar 2 Lukis cadas di Gua Kerbau 
Kawasan kars Bukit Bulan (Gambar 1) selain memiliki potensi sumber daya alam, juga memiliki nilai sejarah yakni ditemukannya situs prasejarah. Terdapat puluhan gua-gua alam yang terdapat di Bukit Bulan dan 5 diantaranya (Gua Sungai Lului, Kerbau 1, Mesiu, Pelaminan Dewa, dan Semedi) terdapat temuan lukisan cadas. Lukisan cadas (Gambar 2) yang ada di gua bisa menjadi bukti adanya hunian masa lalu manusia (Fauzi, 2016). Situs prasejarah ini menarik untuk diteliti, salah satunya melalui aspek botani. Tujuan dari penelitian ini adalah untuk menginvetaris tumbuhan yang ada di kars Bukit Bulan. Dari data hasil penelitian diharapkan bisa menjawab temuan-temuan masa lalu (fosil kayu dan pollen) untuk menarik benang merah dengan masa kini. Selain itu, penelitian ini juga untuk mendeskripsikan pemanfaatan tumbuhan dalam kehidupan seharihari masyarakat setempat (etnobotani).

\section{METODE}

\section{Lokasi dan Waktu Penelitian}

Penentuan lokasi didasarkan pada penelitain Fauzi (2016) guna mendukung penelitian arkeologi. Lokasi yang digunakan dalam penelitian ini adalah kawasan karst Bukit Bulan dan Gua Mesiu yang menjadi fokus penelitian. Penelitian dilakukan bulan Juni sampai Juli 2018 dan Agustus sampai September 2019.

\section{Metode Pengumpulan dan Analisis Data}

Iventarisasi tumbuhan dilakukan dengan cara observasi yang dibantu penduduk lokal. Pencatatan tumbuhan terdiri dari nama lokal dan pemanfaatannya. Untuk melihat komposisi vegetasi dilakukan dengan cara transek garis lurus dari mulut Gua Mesiu hingga tepi Sungai Ketari, kemudian dilakukan pencatatan dan dokumentasi vegetasi. Analisis data dilakukan dengan studi pustaka dengan mengkomparasi data dokumentasi, observasi, dan wawancara.

\section{HASIL DAN PEMBAHASAN}

Masyarakat di kawasan Kars Bukit Bulan sudah lama mengenal berbagai jenis tumbuhan. Mereka sudah memahami nilai ekonomis masing-masing jenis tumbuhan dan salah satunya yang memiliki nilai jual tinggi. Ada beberapa alasan mengapa jenis tumbuhan memiliki nilai tinggi karena ketersediaannya, mutu kayu, dan nilai manfaatnya. Sebagian besar tumbuhan bernilai ekonomi tinggi adalah untuk kayu bangunan. Tabel 1 adalah daftar berbagai jenis tumbuhan yang memiliki nilai ekonomi tinggi yang selama ini banyak dimanfaatkan masyarakat.

Masyarakat di sekitar kars Batu Bulan juga memanfaatkan tumbuh-tumbuhan untuk membuat barang kerajinan (seni kriya). Mereka mamanfaatkan serat tumbuhan sebagai bahan tali atau lembaran untuk anyaman. Sebagai bahan tali, dimanfaatkan beragam jenis rotan, bambu, terap, pandan, dan pelepah pisang. Sebagai bahan anyaman, sebagian memanfaatkan bilahan bambu, rotan, dan pandan. Selain tali dan beragam jenis anyaman, masyarakat setempat juga memanfaatkan berbagai jenis tumbuhan berdaun lebar dan kuat sebagai atap untuk gubuk. Daftar pemanfaatan tumbuhan untuk seni kriya ditunjukkan pada Tabel 2.

Untuk memenuhi kebutuhan pangan, masyarakat setempat memanfaatkan tumbuhan hutan atau tanaman budidaya sebagai bahan pangan. Tabel 3 adalah daftar tumbuhan yang dimanfaatkan sebagai bahan pangan oleh penduduk setempat. Ada bahan pangan yang dikonsumsi langsung, diolah dan ada juga yang diolah menjadi produk turunan. Untuk mengatasi gangguan kesehatan, masyarakat di sekitar Kars Bukit Bulan memanfaatkan tumbuh-tumbuhan sebagai obat tradisional. Tumbuh-tumbuhan didapat di hutan ataupun ada yang ditanam di pekarangan rumah. Tabel 4 adalah daftar tumbuhan obat yang biasa digunakan masyarakat untuk berbagai pengobatan tradisional. Tanaman budidaya banyak dikembangkan di lahan tegal. Tanaman ini menjadi salah satu sumber perekonomian masyarakat dari sektor pertanian. Tabel 5 adalah daftar tanaman budidaya yang kembangkan oleh masyarakat. 
Tabel 1 Tumbuhan bernilai ekonomi tinggi

\begin{tabular}{cllccc}
\hline No & \multicolumn{1}{c}{ Nama Lokal } & \multicolumn{1}{c}{ Nama Ilmiah } & Status IUCN & \multicolumn{1}{c}{ Manfaat } & Keterangan \\
\hline 1 & Karuing & Dipterocarpus spp & & Kayu bangunan & Papan \\
2 & Kayu taji & Podocarpus elongatus & LC & Kayu bangunan & Tiang \\
3 & Ketapang & Terminalia catappa & & Kayu bangunan & Tiang \\
4 & Kulin & Eusideroxylon zwageri & VU & Kayu bangunan & Tiang \\
5 & Mentaling & Ochanostachys amanteacea & & Kayu bangunan & Tiang \\
6 & Meranti & Shorea spp & & Kayu bangunan & Papan \\
7 & Merbau & Intsia bijuga & VU & Kayu bangunan & Papan \\
8 & Modang batu & Cryptocarya crassinervia & & Kayu bangunan & Papan \\
9 & Modang darah/merah & Horsfieldia irya & LC & Kayu bangunan & Papan \\
10 & Modang keladi & Litsea sp & & Kayu bangunan & Papan \\
11 & Modang seluwang & Dacryodes rugosa & & Kayu bangunan & Papan \\
12 & Modang sirai & Actinodaphne procera & VU & Kayu bangunan & Papan \\
13 & Petanang & Dryobalanops oblongifolia & VU & Kayu bangunan & Tiang \\
14 & Plangas & Aporosa aurita & & Kayu bangunan & Tiang \\
15 & Surian & Toona sp & & Kayu bangunan & Papan \\
16 & Tembesu & Fagraea fragrans & VU & Kayu bangunan & Tiang \\
\hline
\end{tabular}

Keterangan: IUCN (international union for the conservation of nature); extinct (EX); extinct in the wild (EW); critically endangered (CR); endangered (EN); vulnerable (VU); near threatened (NT); conservation dependent (CD); least concern (LC)

Tabel 2 Tumbuhan untuk seni kriya

\begin{tabular}{|c|c|c|c|c|c|}
\hline No & Nama Lokal & Nama Ilmiah & Bagian Tumbuhan* & Manfaat & Keterangan \\
\hline 1 & Alang-alang & Imperata cylindrica & Fol & Atap & \\
\hline 2 & Antui beringin kuning & Xylopia malayana & Lig & Kayu & \\
\hline 3 & Antui beringin putih & Polyalthia glauca & Lig & Kayu & \\
\hline 4 & Antui nasi & Cyathocalyx ramuliflorus & Lig & Tali & Pengikat \\
\hline 5 & Antui siamang & Cyathocalyx bancanus & Lig & Tali & \\
\hline 6 & Antui simpai & Cyathocalyx pruniferus & Lig & Tali & \\
\hline 7 & Bambu & Bambusa sp & Lig & Atap & \\
\hline 8 & Bambu & Bambusa sp & Lig & Dinding & Anyaman \\
\hline 9 & Enau & Arenga pinata & Fol & Tali & Anyaman \\
\hline 10 & Jernang & Daemonorops draco & Fru & Pewarna, dupa & Merah muda \\
\hline 11 & Kelapa & Cocos nucifera & Fol & Atap & \\
\hline 12 & Kelundang & & $\operatorname{Rad}$ & Tali & Jerat \\
\hline 13 & Lipai/nipah & Nypa fruticans & Fol & Atap & \\
\hline 14 & Lirik & Labisia pumila & Fol & Atap & \\
\hline 15 & Mengkanang & Alpinia sp & Fol & Atap & Anyaman \\
\hline 16 & Nilau & Commersonia bartramia & Fol & Tali & Pengikat \\
\hline 17 & Pandan & Pandanus sp & Fol & Tikar & Anyaman \\
\hline 18 & Pinang & Areca catechu & Fru & Pewarna & Merah \\
\hline 19 & Pisang & Musa sp & Cor & Tali & Pengikat \\
\hline 20 & Pua batu & Globba pendula & Fol & Atap & Anyaman \\
\hline 21 & Rotan batu & Calamus insignis & Lig & Tali & Anyaman \\
\hline 22 & Rotan dahan & Korthalsia cf. flagellaris & Lig & Tali & Anyaman \\
\hline 23 & Rotan sego & Calamus caesius & Lig & Tali & Anyaman \\
\hline 24 & Rotan seni & Calamus sp & Lig & Tali & Anyaman \\
\hline
\end{tabular}




\begin{tabular}{|c|c|c|c|c|c|}
\hline No & Nama Lokal & Nama Ilmiah & Bagian Tumbuhan* & Manfaat & Keterangan \\
\hline 25 & Rotan tunggal & Calamus laevigatus & Lig & Tali & Anyaman \\
\hline 26 & Rotan udang & Korthalsia echinomerta & Lig & Tali & Anyaman \\
\hline 27 & Rumbai/pandan kecil & Pandanus sp & Fol & Atap & Anyaman \\
\hline 28 & Sungkai & Peronema canescens & Fol & Atap & Anyaman \\
\hline & Surian & Toona $\mathrm{sp}$ & Lig & Atap & Sirap \\
\hline & Terap & Artocarpus elasticus & Cor & Tali & Pengikat \\
\hline & Waru & Hibiscus tiliaceus & Cor & Tali & Pengikat \\
\hline
\end{tabular}

*Keterangan: kulit batang (cortex), batang (caulix), kayu (lignum), daun (folium), bunga (flos), akar (radix), rimpang (rhizoma), buah (fructus), biji (semena), umbi (bulbus)

Tabel 3 Tumbuhan konsumsi

\begin{tabular}{|c|c|c|c|c|}
\hline No & Nama Lokal & Nama Ilmiah & Bagian Tumbuhan* & Manfaat \\
\hline 1 & Cempedak & Artocarpus integer & Fru & Pangan \\
\hline 2 & Duku & Lansium domesticum & Fru & Pangan \\
\hline 3 & Durian & Durio zibethinus & Fru & Pangan \\
\hline 4 & Enau & Arenga pinnata & Fru & Pangan \\
\hline 5 & Jagung & Zea mays & Sem & Pangan \\
\hline 6 & Jengkol & Archidendron pauciflorum & Sem & Pangan \\
\hline 7 & Kabau & Archidendron microcarpum & Sem & Pangan \\
\hline 8 & Keladi & Caladium $\mathrm{sp}$ & Bul & Pangan \\
\hline 9 & Kelapa & Cocos nucifera & Fru & Pangan \\
\hline 10 & Kelengkeng & Dimocarpus longan & Fru & Pangan \\
\hline 11 & Kemiri & Aleurites moluccanus & Sem & Minyak \\
\hline 12 & Kentang & Solanum tuberosum & Rhi & Pangan \\
\hline 13 & Kepayang & Pangium edule & Sem & Minyak \\
\hline 14 & Macang & Mangifera foetida & Fru & Pangan \\
\hline 15 & Manau & Calamus manan & Fru & Pangan \\
\hline 16 & Mangga & Mangifera indica & Fru & Pangan \\
\hline 17 & Mentimun & Cucumis sativus & Fru & Pangan \\
\hline 18 & Nangka & Artocarpus heterophyllus & Fru & Pangan \\
\hline 19 & Nenas & Ananas comosus & Fru & Pangan \\
\hline 20 & Padi & Oryza sativa & Sem & Pangan \\
\hline 21 & Pandan Musang & Pandanus amaryllifolius & Fol & Pangan \\
\hline 22 & $\mathrm{Pao}$ & Mangifera odorata & Fru & Pangan \\
\hline 23 & Pepaya & Carica papaya & Fru & Pangan \\
\hline 24 & Petai & Parkia speciosa & Sem & Pangan \\
\hline 25 & Pisang & Musa sp & Fru & Pangan \\
\hline 26 & Pokak/Langgui & Solanum torvum & Fru & Pangan \\
\hline 27 & Rambutan & Nephelium lappaceum & Fru & Pangan \\
\hline 28 & Sekawang/Tekawang & Shorea sp & Sem & Minyak \\
\hline 29 & Singkong & Manihot esculenta & Bul & Pangan \\
\hline 30 & Sukun & Artocarpus altilis & Fru & Pangan \\
\hline 31 & Talas & Colocasia esculenta & Bul & Pangan \\
\hline 32 & Tampui & Baccaurea macrocarpa & Fru & Pangan \\
\hline 33 & Tebu & Saccharum sp & $\mathrm{Cau}$ & Pangan \\
\hline
\end{tabular}

*Keterangan: kulit batang (cortex), batang (caulix), kayu (lignum), daun (folium), bunga (flos), akar (radix), rimpang (rhizoma), buah (fructus), biji (semena), umbi (bulbus) 
Tabel 4 Tumbuhan bahan obat tradisional

\begin{tabular}{cllcc}
\hline No & \multicolumn{1}{c}{ Nama Lokal } & \multicolumn{1}{c}{ Nama Ilmiah } & Bagian Tumbuhan* & Manfaat \\
\hline 1 & Bawang merah & Alium cepa & bul & Luka bakar \\
2 & Jambu & Psidium guajava & fol & Diare \\
3 & Kayu kundur & Benincasa hispida & fol, Cor & Demam \\
4 & Kunyit & Curcuma domestica & rhi & \\
5 & Nangka & Artocarpus heterophyllus & fru & Diare \\
6 & Rambutan jantan & Nephelium lappaceum & fol, cor & \\
7 & Sahang & Piper nigrum & fol & Diare \\
8 & Singkong & Manihot esculenta & fol & Luka luar \\
9 & Pisang & Muisa sp & lat & Luka luar \\
\hline
\end{tabular}

*Keterangan: kulit batang (cortex), batang (caulix), kayu (lignum), daun (folium), bunga (flos), akar (radix), rimpang (rhizoma), buah (fructus), biji (semena), umbi (bulbus)

Tabel 5 Tanaman perkebunan

\begin{tabular}{|c|c|c|}
\hline No & Nama Lokal & Nama Ilmiah \\
\hline 1 & Cabai & Capsicum $\mathrm{sp}$ \\
\hline 2 & Cokelat & Theobroma cacao \\
\hline 3 & Jagung & Zea mays \\
\hline 4 & Jengkol & Archidendron pauciflorum \\
\hline 5 & Kacang hijau & Vigna radiata \\
\hline 6 & Kacang tanah & Arachis hypogaea \\
\hline 7 & Karet & Hevea brasiliensis \\
\hline 8 & Kopi & Coffea sp \\
\hline 9 & Padi ladang & Oryza sativa \\
\hline 10 & Padi sawah & Oryza sativa \\
\hline 11 & Petai & Parkia speciosa \\
\hline 12 & Pisang & Musa sp \\
\hline 13 & Singkong & Manihot esculenta \\
\hline 14 & Terung & Solanum melongena \\
\hline
\end{tabular}

Tabel 6 Tanaman pembatas, penyela, pagar

\begin{tabular}{|c|c|c|}
\hline No & Nama Lokal & Nama Ilmiah \\
\hline 1 & Bambu & Bambusa sp \\
\hline 2 & Junjung panilai & Gliricidia sepium \\
\hline 3 & Kasai & Pometia sp \\
\hline 4 & Labu kayu & Aegle marmelos \\
\hline 5 & Maja & Crescentia cujete \\
\hline 6 & Medang & Litsea firma \\
\hline 7 & Pinang & Areca catechu \\
\hline 8 & Sungkai & Peronema canescens \\
\hline
\end{tabular}

Lahan pertanian dan pemukiman adalah teritorial pada tiap individu, keluarga atau kelompok tertentu. Banyak lahan yang bersertifikat dan memiliki batasan yang jelas. Untuk membatasi lahan, biasanya masyarakat setempat menggunakan penanda berupa tanaman sebagai tanaman pembatas (Tabel 6). Tanaman pembatas tak semata sebagai batas wilayah, tetapi sekaligus berguna sebagai tanaman pagar untuk melindungi dari serangan 
hama seperti babi, kambing hutan, rusa, dan lain sebagainya. Pemanfaatan tanaman pagar dipilih yang mampu tumbuh dengan cara distek. Sebagai organisme perintis, paku-pakuan memiliki peranan penting dalam vegetasi batuan kapur. Sebagai organisme mula-mula, paku menjadi indikator jika habitat tersebut bisa dijadikan habitat bagi organisme terestrial. Di kawasan Kars Bukit Bulan, setidaknya telah ditemukan sebanyak 15 jenis pakupakuan (Tabel 7).

Tabel 7 Berbagai jenis paku di kars Bukit Bulan

\begin{tabular}{|c|c|c|}
\hline No & Nama Ilmiah & Keterangan \\
\hline 1 & Adiantum caudatum & Di bebatuan \\
\hline 2 & Cibotium baranet & Semak belukar \\
\hline 3 & Davalia denculata & Semak belukar \\
\hline 4 & Davallia tricomonoides & Semak belukar \\
\hline 5 & Diplazium esculentum & Di sayur \\
\hline 6 & Drynaria quercifolia & Pangkal, batang pohon \\
\hline 7 & Drynaria rigidula & Batuan dan batang pohon \\
\hline 8 & Drynaria sparsisora & Batuan dan batang p`ohon \\
\hline 9 & Gleichenia linearis & Lahan kritis \\
\hline 10 & Hephrolepis bisserata & Semak belukar \\
\hline 11 & Hypolepis puncata & Semak belukar \\
\hline 12 & Lindsaea repens & Semak belukar \\
\hline 13 & Selaginella & Semak belukar \\
\hline 14 & Thelypteris palustris & Semak belukar \\
\hline 15 & Tricomonas keysmanii & Batuan \\
\hline
\end{tabular}

\section{Ekologi Kars Bukit Bulan}

Batuan gamping sebagai penyusun lanskap ini, beberapa bagian sudah ditutupi vegetasi, baik tumbuhan tingkat rendah dan tinggi. Lanskap ini yang awalnya adalah dasar lautan yang kemudian terangkat menjadi lahan terestrial belum ada organisme yang hidup, karena belum ada material yang bisa mendukung kehidupan organisme. Lingkungan sekitar kars batu bulan yang sudah berwujud terestrial menjadi suksesi primer flora dan fauna. Migrasi flora dari habitat alaminya ke habitat baru melalui jalur distribusi yang melibatkan; angin (anemokori), air (hidrokori), gravitasi, dan beragam jenis fauna (zookori). Adanya jalur distribusi ini akan memercepat revegetasi permukaan batuan gamping.

Kars sebagai habitat yang unik, menciptakan flora yang memiliki karakteristik tersendiri dibanding dengan ekosistem lainnya. Minimnya tanah, humus/top soil telah menciptakan flora dengan tingkat adaptasi yang tinggi. Adaptasi tersebut dalam bentuk mampu bertahan hidup dalam kondisi yang kering, miskin unsur hara, air yang terbatas, mampu mengembangkan akar udara, dan perakarannya mampu menembus celah-celah sempit di bebatuan (Rahmadi, 2007).

Lumut sebagai organisme pionir mengawali kehidupan lalu disusul oleh paku-pakuan. Kedua organisme ini menciptakan habitat baru yang memungkinkan tumbuhan tingkat tinggi bisa hidup karena tersedianya mulsa sebagai nutrisi yang dibutuhkan. Berjalannya waktu jadilah ekosistem kars yang dihuni oleh beragam jenis flora, sehingga menciptakan mikroklimat tersendiri.

Terbentuknya vegetasi awal ini akan memunculkan datangnya spesies-spesies baru. Spesies baru ini terutama oleh tumbuhan berspora dan berbiji. Gravitasi dan angin memegang peranan penting dalam pemencaran. Spora akan mudah terbang terbawa pergerakan angin dan jatuh lalu memunculkan individu baru, begitu juga dengan biji-bijian. Lewat aliran air saat musim hujan atau saluaran air, juga akan mempermudah distribusi tumbuh-tumbuhan. 
Distribusi yang lebih luas dilakukan oleh fauna pemakan biji dan bebuahan hutan. Beraneka burung dan mamalia adalah agen penyebar bebijian yang efektif dalam pemencaran biji-bijian. Seperti terlihat pada Gambar 3, terdapat 4 jenis biji, yakni kamat, balam merah, ketapang, dan age.

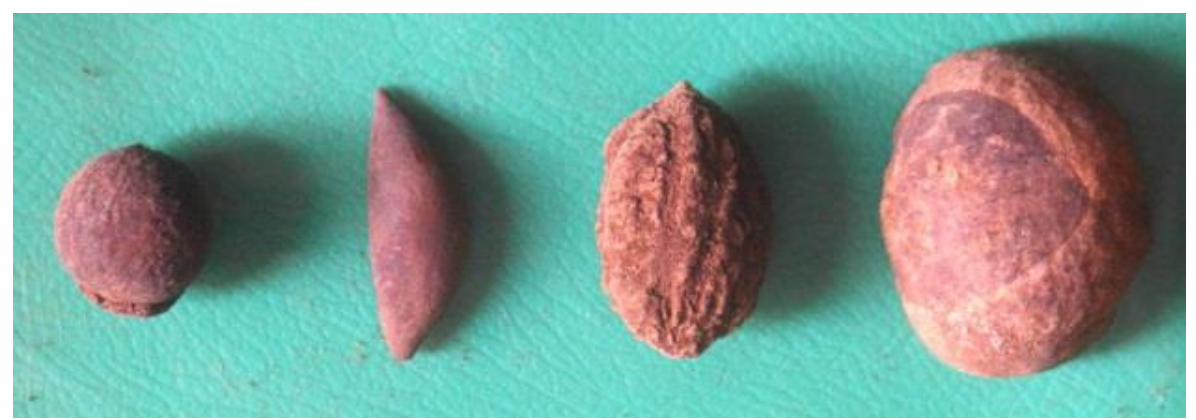

Gambar 3 Biji-bijian yang buahnya dimakan kelelawar dan ditemukan di dalam Gua Mesiu (dari kiri ke kanan: kamat, balam merah, ketapang, age)

Biji-bijian tersebut ditemukan di mulut Gua Mesiu. Biji-bijian tersebut sampai di tempat ini karena dibawa oleh kelelawar (codot dan kalong), karena merupakan makanannya. Keleawar berpesan sebagai pemencar (kiropterokori). Jenis pemencaran lain yang dilakukan hewan antara lain ornitokori yakni yang dilakukan burung pemakan biji dan buah, seperti beringin. Serangga (entomokori) juga berperan sebagai pemencar terutama untuk tumbuhan dengan biji-biji kecil dan berlemak. Mamalia dapat juga sebagai pemencar (mammokori), terutama primata. Di hutan Kars Bukit Bulan terpadat beberapa jenis primata seperti: kera ekor panjang, uwa, dan siamang. Mammokori dapat melalui 2 mekanisme yakni; endozoik (melalui saluran pencernaan) dan eksozoik (menempel pada badan atau bulu). Peran manusia sebagai pemencar (antropokori) juga terlibat dalam proses distribusi fauna, yang dilakukan secara sengaja atau tidak sengaja. Adanya pemencaran ikut memberikan andil dalam pembentukan vegetasi kars di Bukit Bulan. Vegetasi-vegetasi baru tersebut nantinya akan membentuk sebuah ekosistem baru yang di dalamnya terdapat rantai dan jejaring makanan. Ekosistem tersebut akan terbentuk kondisi yang homeostatis dan menjadi lingkungan berciri khas vegetasi kars.

Di kawasan karst Bukit Bulan ada beberapa lokasi hutan yang masih terjaga dengan baik. Salah satu kawasan yang masih terjaga berada di Bukit Raja. Hutan di Bukit Raja adalah hutan lindung yang dikelola oleh masyarakat menjadi hutan adat. Dengan ditetapkannya kawasan ini menjadi hutan adat, maka ada aturan adat yang tidak boleh dilanggar oleh masyarakat. Masyarakat diperbolehkan masuk dalam kawasan hutan untuk mengambil atau memanen sebatas kebutuhan dan tidak boleh diperjual belikan. Hutan adat menyediakan kebutuhan masyarakat, tetapi tidak boleh dieksploitasi yang berakibat buruk bagi lingkungan dan masyarakat. Tata cara ini mirip dengan tata kelola hutan rakyat sebagaimana di ungkapkan oleh Purbawiyatna et al. (2012), pengelolaan hutan rakyat yang dimaksud adalah dalam hal perencanaan, penanaman, pemeliharaan hutan, pemanenan dan penyiapan prasarananya sehingga dihasikan hasil hutan bernilai ekonomis tinggi tanpa menimbulkan dampak merugikan bagi lingkungan maupun sosial.

Salah satu alasan ekologis mengapa masyarakat begitu menjaga hutan adat adalah permasalahan air. Masyarakat di Bukit Bulan mengandalkan Sungai Ketari dan Limun sebagi sumber air untuk kebutuhan seharihari. Masyarakat pada umumnya memiliki persepsi yang baik atas fungsi lindung hutan terutama secara fisik yaitu untuk melindungi sumber mata air dan mencegah erosi serta longsor (Purbawiyatna et al., 2011). Hulu Sungai Ketari dan Limun berada di Bukit Raja, sehingga masyarakat menjaga hutan yang ada di sana dengan baik, bahkan untuk mengkonservasi air dibuat aturan adat berupa lubuk larangan. Di dalam lubuk larangan (sungai adat), masyarakat dilarang memancing, menangkap ikan, membuang sampah, dan mengotori dalam bentuk apapun. Dengan adanya kearifan lokal ini mampu menjaga keberadaan hutan dan sumber air, serta sungai yang ada di Bukit Bulan. 


\section{Vegetasi Gua Mesiu}

Gua Mesiu merupakan salah satu gua yang ada di kars Bukit Bulan tepatnya di sisi selatan Bukit Raja. Gua ini potensial menjadi hunian manusia prasejarah, karena memiliki lingkungan gua yang memenuhi syarat hunian, seperti: kering, dekat dengan sumber air (sungai), memiliki lorong yang luas, aman dari banjir, memiliki akses yang mudah, dan lain sebagainya. Pada penelitian saat ini, dilakukan ekskavasi untuk mendapatkan temuan-temuan bukti prasejarah yang telah terkubur. Salah satu temuan yang nantinya berharap bisa ditemukan adalah fosil kayu dan serbuk sari (pollen).

Untuk menjawab hasil temuan prasejarah di Gua Mesiu juga perlu dilakukan studi vegetasi yang saat ini ada di sekitar Gua Mesiu. Diharapkan ada benang merah antara temuan prasejarah dengan flora yang ada saat ini, terutama di sekitar Gua Mesiu. Adanya keterkaitan dengan vegetasi tersebut bisa menjawab kira-kira kondisi vegetasi masa lalu. Vegetasi dan stratifikasi di sekitar Gua Mesiu ditunjukkan pada Gambar 4.

Dari pola stratifikasi vegetasi di sekitar Gua Mesiu terlihat persebaran beberapa flora yang berbeda-beda. Pada tepian sungai, terlihat bebarapa flora akuatik dari famili poaceae (rerumputan), kemudain di susul bambu. Bambu sebagian besar ditemukan disekitar sungai. Tumbuhan berupa paku-pakuan mendominasi lantai hutan, baik dipermukaan tanah, batuan, dan kulit pohon. Lichens atau lumut kerak juga ditemukan dipermukaan batuan dan kulit pohon. Tumbuhan keras (pohon) ditemukan dan hampir merata. Pohon balam, kasai, pulai, rabo, balam merah, dan beringin dapat dengan mudah ditemukan. Untuk beringin, sebagian besar ditemukan pada batu-batuan dan dinding gua. Ada juga beringin yang ditemukan membelit di pohon lain.

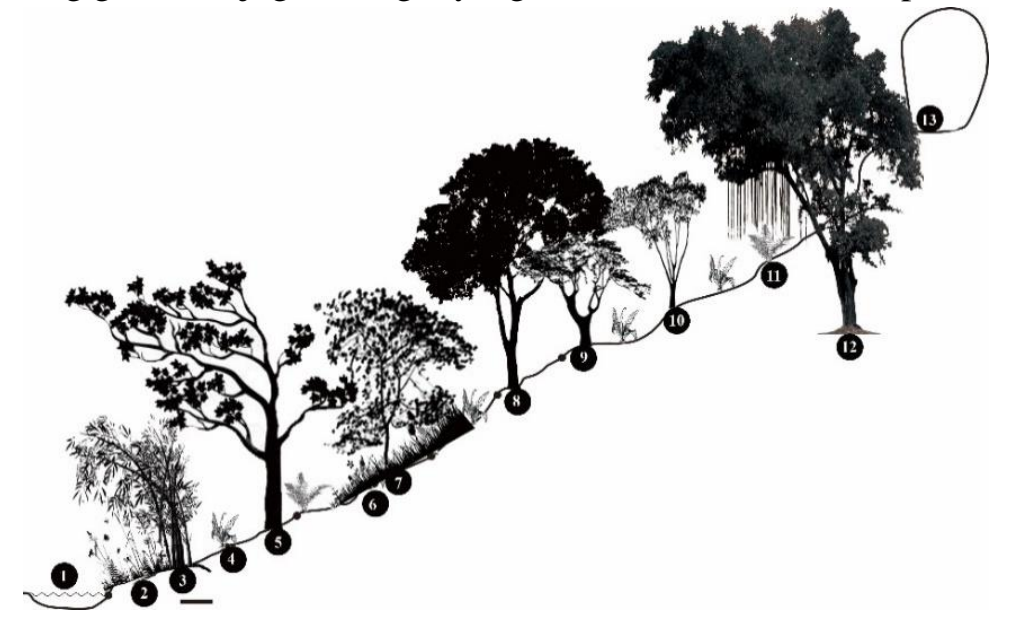

Gambar 4 Stratifikasi Bukit Bulan

(1. sunga katari, 2. semak, 3. bambu, 4. paku, 5. balam putih, 6. semak belukar, 7. kasai merah, 8. pulai, 9. rabo, 10. balam merah, 11. paku, 12. beringing, 13. mulut gua mesiu)

\section{Etnobotani Kars Bukit Bulan}

Dengan adanya temuan situs prasejarah di kars Bukit Bukit bulan berupa lukis cadas (Fauzi, 2016), maka perlu dilakukan kajian etnobotani. Kajian ini untuk melihat tentang pemanfaatan sumber daya alam terutama tumbuhan bagi manusia, baik zaman dahulu atau saat ini. Pemanfaatan tumbuhan sudah banyak dilakukan oleh penduduk lokal yang tinggal di kawasan kars Bukit Bulan. Penduduk sepenuhnya tergantung pada sumber daya alam terutama tumbuhan untuk mendukung kehidupan mereka.

Penelitian sebelumnya yang dilakukan oleh Mahmudah et al. (2012), di hutan adat Imbo Mengkadai Sarolangun-Jambi menjadi referensi dalam penelitian ini. Di hutan adat Imbo Mengkadai ditemukan 176 spesies tumbuhan yang digunakan oleh penduduk setempat. Pemanfaatan tumbuhan meliputi: bahan pangan, konstruksi berat, konstruksi ringan, bahan teknologi lokal dan seni, bahan tali temali, hiasan/adat/ritual, sumber penghasilan, bahan pewarna, dan kayu bakar (Mahmudah et al., 2012). 
Dalam penelitian ini juga telah ditemukan 172 spesies tumbuhan yang digunakan oleh penduduk setempat untuk berbagai keperluan. Penduduk setempat memanfaatkan tumbuhan tersebut sebagai bahan untuk bangunan, kosntruksi non bangunan, pangan, pewarna, adat/ritual dan anyaman. Dalam penelitian ini juga ditemukan pemanfaatan tumbuhan sebagai tanaman budidaya, pembatas/pagar, obat, dan tali-temali.

\section{Kayu Bernilai Ekonomi Tinggi}

Menurut penuturan penduduk di Kars Bukit Bulan, saat ini susah ditemukan kayu yang memiliki nilai ekonomi tinggi. Maraknya penebangan liar dan kebakaran hutan membuat tidak banyak kayu yang tersisa di sana. Ada 16 jenis tumbuhan bernilai ekonomi tinggi yang sebagian besar adalah kayu keras. Tumbuhan ini dikatakan bernilai ekonomi tinggi, karena memiliki kelangkaan di habitat, pasar, manfaatnya banyak, sehingga jika diperjualbelikan akan mahal.

Di kars Bukit Bulan terdapat beberapa hutan lindung, salah satunya di Bukit Raja. Di sekitar daerah tersebut masih terdapat pohon-pohon langka dan bernilai ekonomi tinggi, seperti; surian, ketapang, meranti, merbau, modang, tembesu dan lain sebagainya. Masyarakat menjadikan hutan lindung di Bukit Raja sebagai tempat untuk menjaga kelestarian tumbuhan yang sudah mulai langka ini. Ada aturan adat yang tidak memperbolehkan untuk menebang dan memperjualbelikan kayu dari hutan adat. Ada aturan, jika masyarakat menginginkan kayu dari hutan adat untuk kepentingan yang tidak berorientasi ekonomi (diperdagangkan) boleh mengambil sewajarnya atas izin kepala adat setempat dan diketahui masyarakat. Adanya upaya ini setidaknya masih bisa menjaga kelestarian tumbuhan bernilai ekonomi tinggi yang ada di kars Bukit Bulan.

\section{Kayu Konstruksi Bangunan}

Masyarakat yang tinggal di kars Bukit Bulan tinggal di dalam rumah yang diberi nama rumah tinggi. Rumah tersebut memiliki tiang pancang yang diletakkan di atas batu pondasi (opak) untuk menyangga bangunan. Tujuan rumah dibuat tinggi adalah untuk menghindarkan dari gangguan seperti; binatang liar, banjir, dan merasa lebih aman. Konstruksi bangunan dan komposisi kayu dapat dilihat pada Gambar 5.

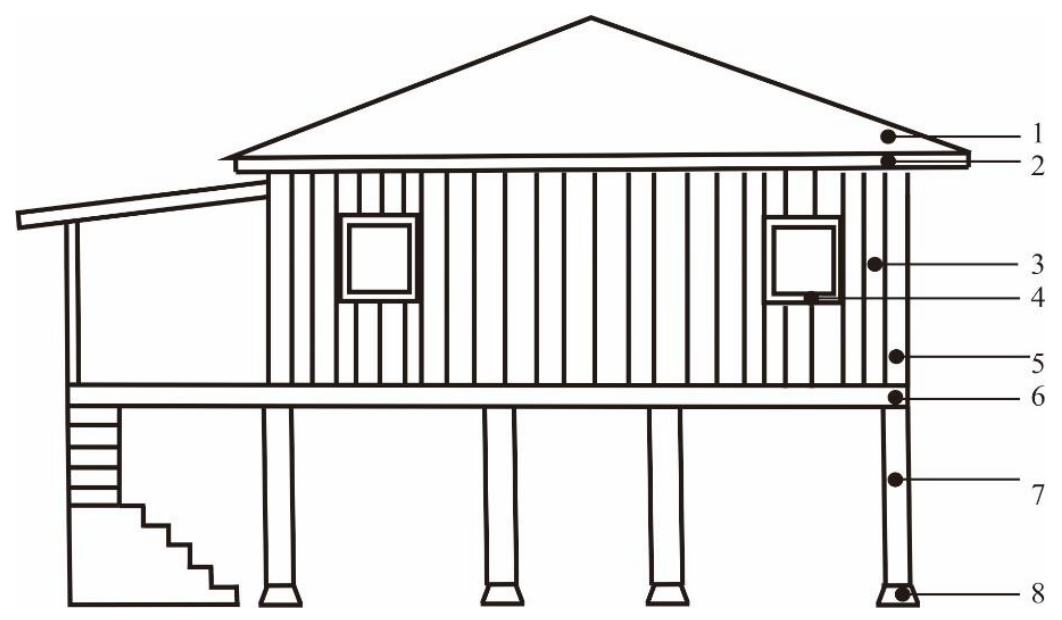

Gambar 5 Rumah hunia warga Napa Melintang, yang disusun dari beragam jenis kayu (1. surian, kepas, sungkai, 2. meranti, malam, 3. meranti, 4. temesu, tahi, medang, 5. asal, 6. meranti, kepas, balam, 7. asal, kelat, keruing, temalun, 8. sondi (batu))

Konstruksi untuk membuat bangunan diambil dari kayu yang berasal dari hutan di sekitaran kars Bukit Bulan. Tiang banguan dibuat dari kayu yang kuat, tahan rayap, keras, dan tahan cuaca, jenis kayunya antara lain; kelat, keruing, temalun. Untuk tiang bagian atas dan kusen digunakan kayu temesu karena sifatnya yang kuat dan mudah dibentuk. Lantai dan dinding bangunan dibuat dari kayu meranti, kepas, dan balam karena 
kuat, dan lebar. Kayu untuk kerangka bagian atas dipilih jenis kayu yang ringan dan kuat yakni meranti dan malam. Atap dari bangunan menggunakan kayu surian, kepas, dan sungkat yang dibuat menjadi sirap. Sebagai pengunci dari sambungan kayu digunakan pasak dari bambu betung.

\section{Tanaman Pagar Halaman}

Untuk membatasi lahan rumah, masyarakat juga menggunakan tanaman pagar dan pembatas. Salah satu tanaman yang dipakai adalah maja. Tanaman maja dipakai karena mudah tumbuh secara vegetatif dengan cara potongan batang yang ditancapkan. Selain itu, masyarakat percaya pohon maja mampu mengusir lintah yang hendak masuk dalam halaman rumah. Selain itu, juga ditanam tanaman pagar seperti jarak, tebu, singkong, pisang, mahkota dewa, seperti ditunjukkan Gambar 6.

Tiang pancang tanaman pagar yang digunakan adalah maja, junjung panilai, atau sungkai yang kemudian akan diisi dengan tanama pagar seperti gamal ahar, sehingga menjadi rapat. Tanaman pagar di sini tidak hanya sebatas sebagai pagar, tetapi juga dimanfaatkan untuk berbagai keperluan. Tebu dimanfaatkan dengan cara dikonsumsi langsung atau diolah menjadi gula tebu dengan cara dimasak hingga kental. Mahkota dewa dimanfaatkan buahnya untuk obat demam. Jarak digunakan daunnya sebagai obat luar, sedangkan bijinya diambil minyaknya untuk lampu. Singkong dimanfaatkan daunnya untuk masakan, dan umbinya sebagai makanan. Pisang dimanfaatkan buahnya sebagai makanan, daunnya sebagai pembungkus makanan, dan serat pelepahnya sebagai tali. Getah pisang juga dimanfaatkan sebagai obat luka luar.

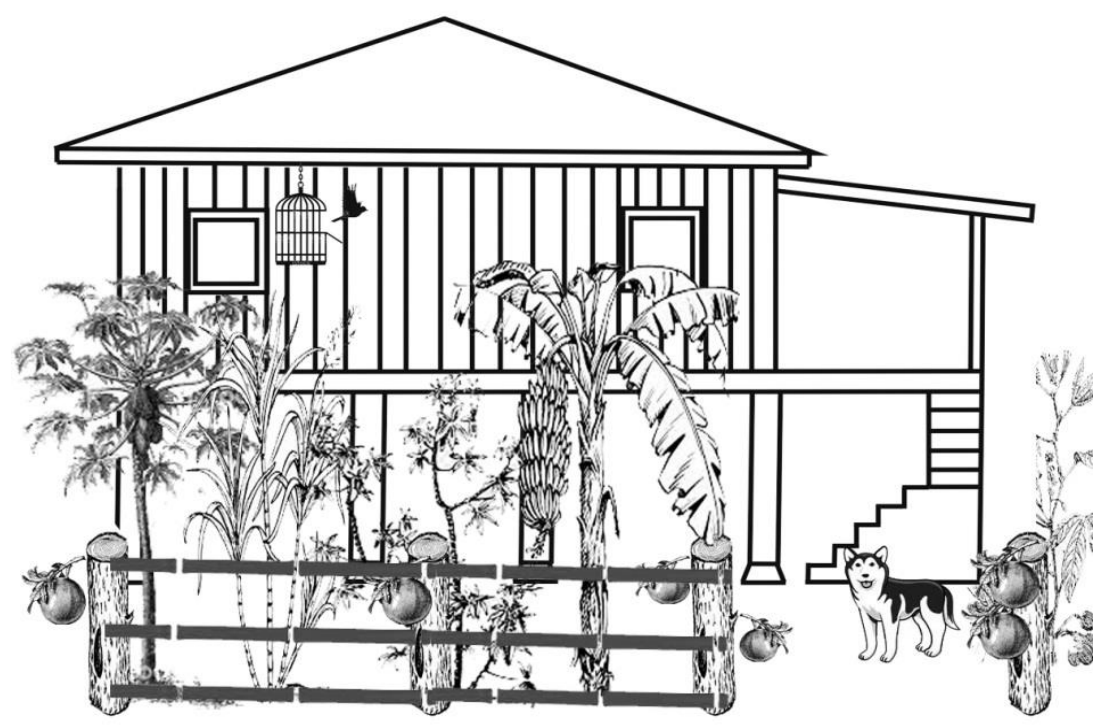

Gambar 6 Pagar halaman rumah warga Dusun Napal Melintang berisikan: maja, pepaya, tebu, singkong, pisang, jarak, dan mahkota dewa

\section{Tanaman Pagar untuk Ladang}

Tanaman pagar juga digunakan untuk memberi batas lahan pertanian dan melindungi dari serangan hama seperti; babi hutan, kijang, landak, kambing hutan, monyet, dan hewan peliharan yang dilepas liarkan (kerbau dan kambing). Tanaman pagar untuk lahan pertanian baik kebun atau ladang dipilih yang kuat dan mudah tumbuh secara vegetatif. Penduduk setempat memanfaatkan potongan kayu sungkai dan junjung paniali, kemudian ditancapkan. Di sela-sela tanaman pagar juga ditanam pinang. Pinang dipilih karena kokoh, berdiri tegak, kuat, dan buahnya bisa dimanfaatkan. Pada Gambar 7 dijelaskan tentang komposisi tanaman pagar untuk lahan perkebunan dan ladang. 


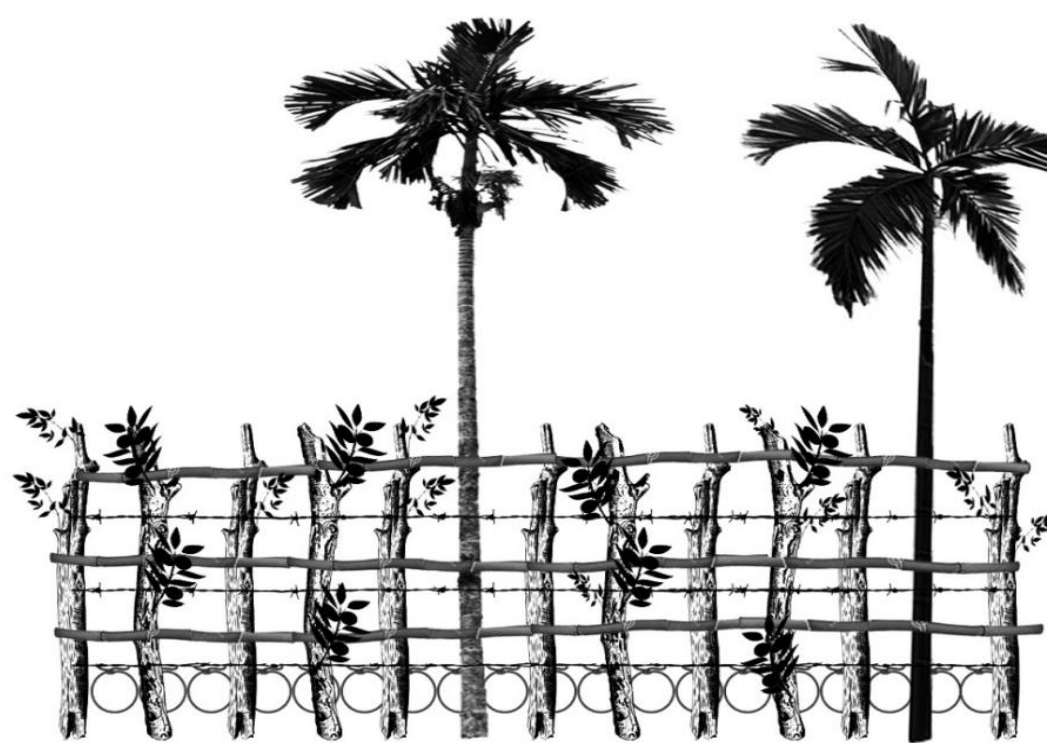

Gambar 7 Pagar kebun dan ladang

Untuk membuat konstruksi pagar yang baik maka digunakan bilahan bambu untuk menghubungkan tiang antar pagar. Tinggi pagar dibuat $130 \mathrm{~cm}$, jarak antar pagar 10 sampai dengan $30 \mathrm{~cm}$. Dibagian bawah pagar ada ruang setinggi $60 \mathrm{~cm}$ dan lebar 10 sampai dengan $30 \mathrm{~cm}$. Ruangan atau rongga tersebut adalah tempat dipasangnya kolong jerat. Jerat terbuat dari kawat berdiameter $3 \mathrm{~mm}$ yang berfungsi sebagai perangkap babi hutan. Diameter perangkap selebar $25 \mathrm{~cm}$. Di atas jerat kawat kemudian dibentangkan kawat berduri setinggi $30 \mathrm{~cm}$ dan $60 \mathrm{~cm}$ yang menghubungkan antar tiang. Beberapa sisi pagar yang tidak terdapat kolong jerat dipasang pakaian bekas yang menurut penduduk setempat, babi sangat sensitif dengan bentuk pakaian dan aroma pakaian manusia.

\section{Serat Tumbuhan}

Di kawasan kars Bukit Bulan, masyarakat memanfaatkan tumbuhan sebagai bahan seni kriya dalam menunjang aktivitasnya. Sebagian besar tumbuhan yang dipakai adalah yang bisa dijadikan tali atau serat. Untuk memanen tali atau serat dapat melalui daunnya (pandan, kelapa, enau), dari batangnya (segala jenis rotan), dari pelepahnya (pisang), dari kulit batangnya (terap, waru), dan dari akar (akar ludang).

Serat alam yang diperoleh dari lingkungan sekitar dimanfaatkan menjadi berbagai kebutuhan dan pembuatan peralatan. Beberapa peralatan yang dibuat dengan menggunakan serat tumbuhan antara lain; tikar, ambung, atap, dinding, bakul, penapis, pengayak, bubu, dan tali. Masyarakat setempat sampai saat ini masih sepenuhnya memanfaatkan serat alam untuk kehidupan mereka.

Pengetahuan lokal tentang berbagai jenis serat alam berikut dengan sifat dan kekuatannnya menjadi pedoman dalam pembuatan alat. Serat dari kulit kayu terap misalnya, dimanfaatkan sebagai tali sandang untuk tas (ambung). Serat terap dipilih karena memiliki sifat yang kuat, lentur, tahan cuaca, dan tahan lama. Serat dari daun pandan dibuat menjadi tikar, karena bentuknya yang pipih dan lebar, liat, dan mudah dianyam. Serat dari kayu waru, memiliki serat yang memanjang, mudah dipilin dan kuat, sehingga dimanfaatkan menjadi tali. Rotan memiliki sifat yang kaku dan kuat, sehingga dimanfaatkan untuk anyaman pada dinding ambung, bakul, penapis, dan pengayak. Serat dari bambu dimanfaatkan sebagian besar sebagai anyaman untuk dinding, bakul, dan bubu, karena memiliki sifat yang tahan air. 


\section{Minyak Nabati}

Masyarakat di Bukit Bulan memanfaatkan minyak nabati yang berasal dari kelapa, jarak, dan sekawang. Untuk memenuhi kebutuhan minyak terutama untuk memasak, masyarakat membuat minyak dari kelapa. Buah kelapa yang sudah masak akan diparut, diperas, kemudian akan dipanaskan hingga terbentuk minyak. Minyak tersebut yang kemudian akan disimpan dan dimanfaatkan sesuai dengan kebutuhan.

Belum adanya aliran listrik membuat masyarakat di Bukit Bulan memanfaatkan minyak jarak sebagai bahan bakar lampu minyak. Biji jarak yang sudah tua diperas dan diambil minyaknya. Minyak biji jarak kemudian dimasukkan dalam botol penampungan yang bagian atasnya sudah dipasang sumbu. Minyak dari biji jarak menjadi bahan bakar untuk lampu penerangan saat malam tiba. Namun saat ini minyak biji jarak tersebut sudah banyak digantikan oleh minyak solar.

Selain minyak kelapa sebagai bahan masakan, digunakan juga minyak sekarang sebagai lauk pauk, bumbu, dan minyak tumis. Sekawang atau meranti merah adalah tumbuhan kayu keras yang menghasilkan buah dan biji. Biji yang dihasilkan kemudian akan ditumbuk halus dan disaring. Serbuk biji sekarang kemudian akan dimasukkan dalam bambu imbo (bambu yang kayunya tipis) lalu dipadatkan dan ditutup dengan daun pisang. Setelah itu akan dipanggang di atas bara api seperti proses pembuatan nasi lemang. Saat sudah matang, serbuk biji sekawang akan dikeluarkan lalu akan ditekan hingga keluar minyaknya. Minyaknya akan terlihat berwarna hitam dan kental, serta memiliki aroma yang khas. Masyarakat di Bukit Bulan mengonsumsi minyak tersebut sebagai lauk dicampur dengan nasi putih. Minyak sekarang juga dimanfaatkan sebagai bumbu masakan atau sebagai minyak untuk menumis. Ekstrak Minyak Sengkawang menghasilkan 20 senyawa bioaktif yang dapat berpotensi untuk diaplikasikan dalam bidang pangan, kosmetik, industri, dan farmasi (Puspita et al., 2019).

\section{Tumbuhan Obat}

Sudah adanya fasilitas kesehatan dan warung-warung yang menjual obat tidak lantas membuat masyarakat di Bukit Bulan meninggalkan obat-obatan tradisional. Beberapa penyakit yang sudah mereka kenal akan diatasi dengan obat-obatan tradisional yang diwariskan nenek moyang mereka. Mereka akan memanfaatkan tumbuhan atau tanaman yang ada di sekitar mereka.

Adanya kesadaran akan kesehatan dan ancaman penyakit, masyarakat di Bukit Bulan menanam beberapa tanaman obat di halaman rumah mereka. Mereka menanam kunyit, jambu, jarak, mahkota dewa, dan lain sebagainya. Dengan adanya tanaman ini, maka akan mempermudah mereka dalam menggunakannya.

Beberapa penyakit yang sering mereka alami antara lain; diare, demam, batuk, pilek, dan luka luar. Untuk penyakit diare digunakan buah nangka muda yang makan langsung dengan diolesi garam. Untuk mengobati demam digunakan rebusan kulit buah mahkota dewa kemudian diminum. Batuk dan pilek digunakan campuran jahe dan kunyit yang direbus kemudian diminum. Untuk luka luar atau terkena benda tajam maka akan diolesi dengan getah dari pelepah pisang.

\section{Tumbuhan Paku}

Tumbuh-tumbuhan (paku) di kawasan kars memiliki tingkat keendemisan yang tinggi karena berada di lingkungan yang spesifik/unik (Rahmadi, 2007). Dari hasil penelitian, ditemukan 15 jenis paku-pakuan di kars Bukit Bulan. Sebagai organisme pionir, paku-pakun disinyalir merupakan organisme yang tumbuh pada awal pembentukan vegetasi di lokasi ini.

Perlu adanya pembuktian tentang paku sebagai flora awal mula. Melalui studi pollen dapat digunakan untuk mengidentifikasi jenis flora pada masa lalu. Pada kawasan kars di Gunung Seweu ditemukan pollen paku jenis polydium, pteris, dan cyatea (Faida et al., 2011). Dari hasil temuan tersebut bisa menjadi dasar untuk penelitian lanjutan mengenai paku-pakuan pada masa lalu melalui studi studi pollen. 
Paku-pakuan yang ada di kars Bukit Bulan belum sepenuhnya dimanfaatkan oleh masyarakat. Hanya paku jenis Diplazium esculentum yang dimanfaatkan sebagai sayur-sayuran. Daun yang masih muda, diambil kemudian dimasak dan dikonsumsi. Belum ada pemanfaatkan paku-pakuan sebagai tanaman hias atau eksploarasi jenis paku-pakuan lain untuk bahan pangan.

\section{KESIMPULAN}

Dari hasil penelitian ini telah diidentifikasi 16 tumbuhan bernilai ekonomi tinggi, 31 tumbuhan untuk seni kriya, 33 tumbuhan untuk konsumsi, 9 tanaman obat, 14 tanaman perkebunan, 8 tanaman pembatas/pagar, dan 15 jenis paku-pakuan. Hasil identifikasi tersebut di atas, hanya tumbuhan yang sudah dikenali dan familiar bagi masyarakat berkaitan dengan etnobotani setempat.

\section{UCAPAN TERIMA KASIH}

Terimakasih kepada Balai Arkeologi Sumatera Selatan yang telah memberikan kesempatan pada penulis bergabung dalam penelitian arkeologi di kawasan kars Bukit Bulan.

\section{DAFTAR PUSTAKA}

Adji TN, Haryono E, Woro S. 1999. Kawasan karst dan prospek pengembangannya di Indonesia. Prosiding Seminar PIT IGI. Jakarta (ID): Universitas Indonesia.

Faida LRW, Sutikno, Fandeli C, Sunarto. 2011. Rekonstruksi hutan purba di kawasan karst gunung sewu dalam periode sejarah manusia. Jurnal Ilmu Kehutanan. 5(2): 79-90.

Fauzi MR. 2016. Beberapa hasil awal penelitian arkeologi di kawasan kars bukit bulan, Sarolangun. Siddhayatra Jurnal Arkeologi. 21(1): 1-12.

Mahmudah RH, Walujo EB, Wardhana W, Susanti T. 2012. Keanekaragaman spesies tumbuhan berguna di hutan adat imbo mengkadai Sarolangun, Jambi. Prosiding Seminar Nasional MIPA dan Pendidikan MIPA. 221-229.

Oktariadi O, Tarwedi E. 2011. Klasifikasi kars untuk kawasan lindung dan kawasan budi daya: Studi kasus kars Bukit Bulan Kabupaten Sarolangun, Provinsi Jambi. Jurnal Lingkungan Dan Bencana Geologi. 2(1): 1-19.

Purbawiyatna A, Kartodihardja H, Alikodra HS, Prasetyo LB. 2011. Analisis kelestarian pengelolaan hutan rakyat di kawasan berfungsi lindung. Jurnal Pengelolaan Sumberdaya Alam dan Lingkungan. 1(2): 8492.

Purbawiyatna A, Kartodihardja H, Alikodra HS, Prasetyo LB. 2012. Analisis kebijakan pengelolaan hutan rakyat untuk mendorong fungsi lindung. Jurnal Pengelolaan Sumberdaya Alam dan Lingkungan. 2(1): $1-10$.

Puspita D, Wulandari TS, Wahyu FD, Rahardjo M. 2019. Analisis senyawa bioaktif dalam minyak sengkawang (Shorea sumatrana) dengan GC-MS. Journal of Food Technology and Nutrition. 18(2): 64-73.

Rahmadi C. 2007. Ekosistem karst dan gua. Kapedal Gunung Kidul. 1-9.

Widiyanti P, Kusmana C. 2014. Komposisi jenis dan struktur vegetasi pada kawasan karst Gunung Cibodas, Kecamatan Ciampea, Kabupaten Bogor. Jurnal Silvikultur Tropika. 5(2): 69-76. 